\title{
ANALISIS PENGARUH EKUITAS MEREK (BRAND EQUITY) TERHADAP KEPUTUSAN PEMBELIAN MOBIL DAIHATSU AYLA DI PT ASTRA INTERNASIONAL TbK GIANYAR
}

\author{
Desak Putu Putri Ayuni ${ }^{1}$ \\ Bagus Arya Wijaya ${ }^{2}$ \\ ${ }^{1,2}$ Fakultas Ekonomi Universitas Ngurah Rai, Bali, Indonesia \\ 1e-mail : putriayuni420@gmail.com
}

\begin{abstract}
ABSTRAK
Era global merubah segalanya menjadi cepat, hal ini menuntut perusahaan untuk membuka diri terhadap tuntutan perubahan, dan berupaya untuk menyusun strategi serta berbagai kebijakan yang sesuai dengan lingkungan baru. Penelitian ini dilakukan di PT Astra Internasional Tbk Gianyar. Tujuan penelitian ini untuk mengetahui untuk mengetahui seberapa besar pengaruh ekuitas merek terhadap keputusan pembelian. Jenis penelitian yang digunakan dalam penlitian ini yaitu penelitian asosiatif dengan pendekatan kuantitatif. Populasi pada penelitian ini adalah seluruh konsumen yang membeli mobil Daihatsu ayla dengan jumlah sampel sebanyak 68 orang. Teknik analisis data yang digunakan adalah metode uji instrument, uji asumsi klasik, analisis regresi linier sederhana, koefisien determinasi, dan uji t. pengujian ini menggunakan bantuan IBM Spss Statistic 24. Hasil penelitian menunjukkan bahwa nilai thitung variabel ekuitas merek sebesar 3,132 $>\mathrm{t}_{\text {tabel }}$ sebesar 1,661 dengan sig. sebesar 0,000 yang artinya variabel ekuitas merek berpengaruh positif dan signifikan terhadap keputusan pembelian.
\end{abstract}

Kata kunci : Ekuitas Merek (Brand Equity), Keputusan Pembelian

\section{ABSTRACT}

The global era is changing everything quickly, this requires companies to open themselves to the demands of change, and strive to develop strategies and policies that are appropriate for the new environment. This research was conducted at PT Astra Internasional Tbk Gianyar. The purpose of this study is to find out how much influence brand equity has on purchasing decisions. This type of research used in this research is associative research with a quantitative approach. The population in this study were all consumers who bought Daihatsu ayla cars with a total sample of 68 people. The data analysis technique used was the instrument test method, the classic assumption test, simple linear regression analysis, the coefficient of determination, and the t test. This test uses the help of IBM Spss Statistics 24. The results showed that the t-value of brand equity variables was 3.132> ttable of 1.661 with sig. equal to 0,000 which means that brand equity variables have a positive and significant effect on purchasing decisions.

Keywords: Brand Equity, Purchasing Decisions 


\section{PENDAHULUAN}

Era global merubah segalanya menjadi cepat, hal ini menuntut perusahaan untuk membuka diri terhadap tuntutan perubahan, dan berupaya untuk menyusun strategi serta berbagai kebijakan yang sesuai dengan lingkungan baru. Perlu adanya strategi yang dilakukan atas perubahan kondisi lingkungan yang terus secara terus menerus harus diupayakan dengan cara mengembangkan program-program yang mampu menerjemahkan dan mengakomodasi permasalahan permasalahan terkini yang muncul.

Merek (brand) adalah salah satu faktor penting dalam kegiatan pemasaran. Merek merupakan identitas dari sebuah produk, merek memberikan suatu informasi yang ringkas tentang suatu produk yang diinginkan oleh konsumen. Merek (brand), merupakan salah satu upaya perusahaan untuk memertahankan dan meningkatkan nilai dari suatu merek yang disebut ekuitas merek (brand equity).

Perusahaan yang menjadi obyek penelitian ini adalah pada perusahaan yang bergerak dalam bidang industri otomotif, berupa penjualan dan service mobil merek Daihatsu yang telah terkenal di wilayah Bali.

Tujuan dalam penelitian ini adalah untuk mengetahui apakah ekuitas merek berpengaruh positif dan signifikan terhadap keputusan pembelian.

Adapun data penjualan mobil merek Daihatsu yaitu sebagai berikut :

Tabel 1

Data Penjualan Mobil Merek Daihatsu Tahun 2016-2018

\begin{tabular}{|l|c|c|c|}
\hline \multirow{2}{*}{$\begin{array}{c}\text { Daihatsu } \\
\text { Type }\end{array}$} & \multicolumn{3}{|c|}{ Tahun } \\
\cline { 2 - 4 } & 2016 & 2017 & 2018 \\
\hline PU & 94 & 125 & 64 \\
\hline TERIOS & 90 & 101 & 20 \\
\hline XENIA & 133 & 175 & 96 \\
\hline AYLA & 63 & 91 & 63 \\
\hline SIRION & 4 & 4 & 1 \\
\hline LUXIO & 4 & 4 & 6 \\
\hline SIGRA & 74 & 91 & 55 \\
\hline TOTAL & 464 & 591 & 305 \\
\hline
\end{tabular}

Sumber : Astra Internasional Gianyar
Berdasarkan
tabel 1, data
khususnya monil merek ayla yang tiga penjualan mobil
merek Daihatsu tahun terakhir mengalami fluktuasi. 


\section{METODE PENELITIAN}

Desain penelitian yang digunakan dalam penelitian ini adalah penelitian asosiatif dengan pendekatan kuantitatif. Teknik pengumpulan data yang digunakan dalam penelitian ini dilakukan dengan observasi, kuisioner, wawancara, dan studi dokumentasi. Teknik analisis data dalam penelitian ini menggunkan pendekatan kuantitatif yaitu analisis statistic inferensial, terdiri dari : uji asumsi klasik, analisis regresi linier sederhana, koefisien determinasi, dan uji t.

\section{HASIL DAN PEMBAHASAN \\ Uji Asumsi Klasik}

Uji asumsi klasik digunakan untuk mengetahui kelayakan penggunaan model regresi. Hasil uji normalitas dapat dilihat pada Tabel 2.

Tabel 2

Hasil Uji Normalitas

\begin{tabular}{|l|c|}
\hline & Unstandardized Residual \\
\hline $\mathrm{N}$ & 68 \\
Kolmogorov-smirnov & 0,200 \\
Asymp.sig (2-tailed) & 0,084 \\
\hline \multicolumn{2}{|l|}{ Sumber: Hasil Olah Data IBM Spss Statistic 24 }
\end{tabular}

Berdasarkan perhitungan pada tabel 2 dapat dilihat bahwa nilai asymp.sig(2-tailed) adalah 0,084. Artinya nilai ini lebih besar dari 0,05. maka dapat disimpulkan bahwa data pada penelitian ini berdistribusi normal

Hasil uji autokorelasi dapat dilihat pada Tabel 3 .

Tabel 3

Hasil Uji Autokorelasi

\begin{tabular}{|c|c|c|c|c|}
\hline DW & DL & DU & 4-DL & 4-DU \\
\hline 1,864 & 1,5470 & 1,6678 & 2,453 & 2,3322 \\
& & & & \\
\hline
\end{tabular}

Sumber : Hasil Olah Data IBM Spss Statistic 24

Berdasarkan tabel 3 bahwa nilai DW yaitu 1,864, DL menunjukkan bahwa nilai sesuai dengan tabel DurbinWatson (DW) $5 \%$ yaitu 1,5470 , DU menunjukkan bahwa nilai sesuai dengan tabel Durbin-Watson (DW) 5\% yaitu 1,6678, 4-DL menunjukkan bahwa nilai sesuai dengan ketentuan yaitu 2,4530, 4-
DU menunjukkan bahwa nilai sesuai dengan ketentuan yaitu 2,3322. Dari uji autokorelasi tersebut, maka DU < DW < 4-DU yaitu $1,6678<1,864<4-2,3322$ sehingga $\mathrm{H}_{0}$ diterima.

Hasil uji heteroskedastisitas dapat dilihat pada Tabel 4. 
Tabel 4

Hasil Uji Heteroskedastisitas

\begin{tabular}{|c|c|c|}
\hline Model & $\mathrm{T}$ & Sig. \\
\hline Constant & $-1,818$ & 0,074 \\
\hline Ekuitas merek & 2,651 & 0,010 \\
\hline
\end{tabular}

Dependent variable : RES2

Sumber : Hasil Olah Data IBM Spss Statistic 24

Berdasarkan tabel 4 dapat diketahui nilai signifikansi antara variabel independen dengan nilai absolut residualnya (ABS_RES) lebih besar dari 0,05 . Hal ini berarti tidak terjadi gejala Heteroskedastisitas pada model regresi.
Analisis Regresi Linier Sederhana

Hasil regresi linier sederhana dapat dilihat pada Tabel 5.

Tabel 5

Hasil Analisis Regresi Linier Sederhana

\begin{tabular}{|c|c|c|}
\hline Model & B & Std.eror \\
\hline Constant & 9,820 & 3,132 \\
\hline Ekuitas merek & 0,491 & 0,063 \\
\hline
\end{tabular}

Berdasarkan tabel 5 diperoleh hasil sebagai berikut : $\mathrm{Y}=9,820+$ $3,132 X$ Persamaan regresi tersebut dapat dijelaskan sebagai berikut $: a=9,820$ merupakan nilai konstanta, jika nilai variabel ekuitas merek (X) adalah nol maka keputusan pembelian

(Y) sebesar 9,820\%. bX $=3,132$ menunjukkan bahwa apabila ekuitas merek meningkat sebesar satu satuan maka keputusan pembelian bertambah sebesar 3,132 . Koefisien regresi tersebut bernilai positif sehingga dapat dikatakan bahwa arah pengaruh variabel $\mathrm{X}$ terhadap $\mathrm{Y}$ adalah positif.

\section{Koefisien Determinasi $\left(\mathbf{R}^{\mathbf{2}}\right)$ \\ Hasil Koefisien Determinasi dapat dilihat pada Tabel 6.}

Tabel 6

Hasil Koefisien Determinasi $\left(\mathrm{R}^{2}\right)$

\begin{tabular}{|c|c|c|}
\hline Model & $\mathrm{R}$ & $R$ square \\
\hline 1 & 0,482 & 0,474 \\
\hline
\end{tabular}

Sumber: Hasil Olah Data IBM Spss Statistic 24 
Berdasarkan tabel 6 dapat dilihat Angka $\mathrm{R}$ square $\left(\mathrm{R}^{2}\right)$ sebesar $0,474(47,4 \%)$ menunjukkan bahwa ekuitas merek (X) mampu menjelaskan keputusan pembelian (Y) sebesar 47,4\%. Sedangkan sisanya sebesar 52,6\% dapat dijelaskan oleh faktor - faktor lain yang tidak diteliti dalam penelitian ini.

Uji t (test)

Hasil uji t(test) dapat dilihat pada tabel 7.

Tabel 7

Hasil Analisis Uji t-test

\begin{tabular}{|c|c|c|}
\hline Model & $\mathrm{t}$ & Sign.t \\
\hline Constant & 5,149 & 0,000 \\
\hline Ekuitas merek & 3,132 & 0,003 \\
\hline
\end{tabular}

Sumber: Hasil Olah Data IBM Spss Statistic 24

Berdasarkan tabel 7 dapat dilihat bahwa variabel ekuitas merek berpengaruh secara parsial terhadap keputusan pembelian. Hal ini dapat dilihat dari signifikan ekuitas merek yaitu 0,05>0,00 dan nilai $t$ hitung variabel ekuitas merek sebesar 3,132 > $t$ tabel sebesar 1,668 maka $\mathrm{H}_{0}$ ditolak dan Ha diterima.

\section{PENUTUP}

\section{KESIMPULAN}

Berdasarkan uraian yang telah dipaparkan pada bab - bab sebelumnya maka dapat disimpulkan yaitu : hasil analisis data dari penelitian ini adalah terdapat pengaruh yang signifikan antara ekuitas merek terhadap keputusan pembelian mobil Daihatsu ayla. Hasil ini diketahui dari uji hipotesis yaitu uji signifikan parsial (uji t) nilai thitung variabel ekuitas merek adalah 3,132 dengan tingkat signifikansi 0,000 dan nilai ttabel 1,668 maka thitung lebih besar dari ttabel $(3,132>1,668)$ dan nilai signifikansinya $0,05>0,00$ itu artinya $\mathrm{Ha}$ diterima. Hasil koefisien determinasi $\mathrm{R}$ square yang diperoleh sebesar 0,474 $(47,4 \%)$ menunjukkan bahwa ekuitas merek (X) mampu menjelaskan keputusan pembelian (Y) sebesar 47,7\%. Sedangkan sisanya sebesar $52,6 \%$ dapat dijelaskan oleh faktor-faktor lain yang tidak diteliti dalam penelitian ini.

\section{SARAN-SARAN}

Dari kesimpulan yang telah diuraikan diatas, maka selanjutnya dapat diberikan saran yaitu sebagai berikut :

a. PT Astra Internasional Tbk, seharusnya dapat memanfaatkan peluang ini dengan melakukan inovasi lagi terhadap kualitas produk mereka dengan memberikan keuntungan apa yang akan didapatkan oleh konsumen serta iklan yang sangat gencar untuk membangun kesan kualitas yang kuat.

b. PT Astra Internasional Tbk harus lebih optimal dalam menggarap atau mengedukasi target marketnya, seperti mengadakan event - event yang disponsori oleh perusahaan, yang nantinya akan 
meningkatkan loyalitas terhadap produk tersebut.

\section{DAFTAR PUSTAKA}

Aaker, David A. 2013. Manajemen Pemasaran Strategi. Edisi kedelapan. Jakarta: Salemba Empat

Afan ,dkk. 2018. Analisis Pengaruh Brand Equity, Harga dan Kepuasan Konsumen terhadap Keputusan Pembelian Sepeda Motor Merek Kawasaki (Studi Pada Konsumen Sepeda Motor Kawasaki Ninja 250 di Boyolali. Boyolali : Universitas Muhammadiyah.

Amirudin, saly. 2017. Analisis Pengaruh Ekuitas Merek terhadap Keputusan Pembelian IPHONE (Studi Kasus Pada Masyarakat Di Kota Pekanbaru). Pekanbaru : STIE Pelita.

Chepi Nurdiansyah. 2018. Pengaruh ekuitas merek dan rasa percaya diri konsumen terhadap keputusan pembelian sarung BHS (studi kasus pada Toko AL-Bagdadi). Jakarta : Akademi Komunikasi BSI Jakarta.

Gede Suasana, Vania Dwi. 2018. Pengaruh elemen ekuitas merek terhadap keputusan pembelian di gerai Starbucks Coffee (studi pada konsumen domestic Starbucks Coffee di wilayah Bali). Bali : Universitas Udayana.

Kotler, Philip. \& Gary Armstrong. 2014. Principle Of Marketing, 15th Edition. New Jersey: Pearson Prentice Hall

Kotler, Philip and Kevin Lane Keller, 2016. Marketing Management. 15th Edition. New Jersey: Pearson Education,Inc.

Sangadji, E. M., \& Sopiah, 2013. Consumer Behavior: Perilaku Konsumen dan.
Strategi Pemasaran Jilid 2. Jakarta: Erlangga

Sari, yuniar. 2015. Analisis pengaruh ekuitas merek terhadap keputusan pembelian mobil kia picanto (studi pada konsumen kia picanto di dealer kia mobil Dinamika semarang). Semarang : Universitas Diponegoro Semarang.

Simamora, Henry. 2013. Pengantar Akuntansi II. Jakarta: Bumi Aksara

Sugiyono. 2017. Metode penelitian pendidikan. Bandung: Alfabeta

Suparyanto \& Rosad. 2015. Manajemen Pemasaran. Bogor: In Media.

Sari, yuniar. 2015. Analisis pengaruh ekuitas merek terhadap keputusan pembelian mobil kia picanto (studi pada konsumen kia picanto di dealer kia mobil Dinamika semarang). Semarang : Universitas Diponegoro Semarang. 